DOI

\title{
КОНЦЕПЦІЯ ПІДГОТОВКИ СТУДЕНТІВ-МЕДИКІВ ЗА ПРОГРАМОЮ ОФІЦЕРА ЗАПАСУ
}

\author{
ДВНЗ “Тернопільський державний медичний університет \\ імені І. Я. Горбачевського МОЗ України”
CONCEPTION OF TRAINING OF MEDICAL STUDENTS BY THE PROGRAM OF A RESERVE OFFICER \\ R. I. Tsytsiura \\ SHEI “Ternopil State Medical University by I. Ya. Horbachevsky of MPH of Ukraine”
}

\author{
P. I. Цицюра
}

\begin{abstract}
Військова підготовка за програмою офіцера медичної служби запасу повинна стати нормативною дисципліною, торкатися всіх студентів-медиків, які за станом здоров'я придатні до військової служби. Навчання відбувається послідовно із врахуванням сучасних досягнень військової медицини з постійною перепідготовкою на післядипломному рівні.

Military training by the program of reserve officer of medical service should be the normative discipline and concern all medical-students, who are suitable for military service. Training is consistently taking into account the achievements of modern military medicine with continuous re-training at postgraduate level.
\end{abstract}

Вступ. На початку III тисячоліття Європа, як і весь світ, вступив в еру нових викликів, де існуючі системи міжнародної безпеки показали свою неспроможність. Стало очевидним, що тільки потужна, мобільна, добре оснащена і мотивована армія спроможна стати на заваді будь-якої зовнішньої чи внутрішньої агресії. Україна, в силу свого геополітичного становища, на багато десятиліть приречена бути на границі розмежування двох політичних, культуральних і ціннісних систем, що породжує загрозу збройних конфліктів, тероризму та хаосу в різних сферах життя держави. 3 моменту початку антитерористичної операції в Україні стала очевидною недостатня підготовка військовослужбовців 3 домедичної допомоги в повсякденний час та бойових умовах, з надання кваліфікованої медичної допомоги цивільними медиками при бойовій травмі. Для вирішення цієї проблеми з 2014-2015 н. р. постало питання про відновлення військових кафедр $[1,2]$. За рахунок бюджету годин елективних курсів була запроваджена дисципліна “Загальна військова підготовка” на I курсі медичних факультетів, за рахунок годин із окремих нормативних дисциплін у навчальні плани були включені питання військовопольової терапії, хірургії, гігієни та епідеміології. Однак на сьогодні стає очевидним, що такий під-

() Р. І. Цицюра хід не вирішить поставлене завдання. Внаслідок скорочення обсягу педагогічного навантаження до 600 год знизився й обсяг елективних курсів. В сумі протягом 6 років навчання годин елективних курсів стало недостатньо для відпрацювання підготовки студентів за програмою офіцерів запасу. Тобто головний задум щодо відновлення військових кафедр таким способом став нереальним.

Мета роботи - обгрунтувати концепцію підготовки студентів-медиків за програмою офіцера запасу.

Основна частина. Підготовка студентів-медиків за програмою офіцера запасу повинна стати нормативною дисципліною, викладатися послідовно впродовж шестирічного навчання та інтернатури для всіх студентів. Посвідчення офіцера відповідної військово-облікової спеціальності отримує спеціаліст (магістр), який придатний за станом здоров'я, пройшов навчальний збір і прийняв Військову присягу після присвоєння кваліфікації.

Обсяг підготовки офіцерів розраховується, виходячи із потреб вірогідного військового конфлікту з можливістю ротації та потреб територіальної самооборони. Крім цього лікарі - офіцери запасу є резерв Державної служби медицини катастроф для посилення лікувальних закладів у випадку надзвичайних ситуацій із масовим потоком поранених.

Загально-військова підготовка вивчається на I курсі і має за мету виробити у студентів армійську 
дисциплінованість, роботу в команді, повагу до командирів і підлеглих. Заняття студенти відвідують в уніформі із відповідними позначками на погонах. Дозволяється заохочення студентів із відповідними відзнаками на уніформі. Заняття розпочинається із шикування, доповіді командиру.

Загальну тактику і військову топографію студенти вивчають на II курсі. Рівень підготовки торкається застосування батальйону у вірогідних військових конфліктах. Зосереджується увага на загальних принципах злагодженості і поведінки військовослужбовця при веденні різних видій бойових дій, які забезпечують виконання бойового завдання та максимально спрямовані на його виживальність у бою, розробляється відповідний перелік типових сценаріїв бойових зіткнень та практичних навичок. 3 цього моменту студенти на практичних заняттях, крім уніформи, дооснащуються касками, тактичними окулярами і рукавицями, бронежилетами, налокітниками і наколінниками, а також масооб’ємними макетами автоматів. Допускається придбання студентами цих засобів (за виключенням автоматів) за демпінговими цінами як засобів самозахисту на випадок мобілізації із відповідною відміткою у посвідченні курсанта військової кафедри. Важливим елементом є вивчення різних типів ручної вогнепальної зброї. Доцільною є організація тиру із відпрацювання практичних навичок стрільби із пневматичної гвинтівки і пістолета.

Одночасно студенти вивчають основи тактичної медицини - організацію і надання домедичної допомоги під час виконання бойових дій (розроблених сценаріїв) під вогнем, на етапі переміщення та у безпечній зоні. Сюди входить само- і взаємодопомога. Студенти дооснащуються аптечками і розгрузками. 3 цією метою розгортаються мінінавчальні полігони із стандартом оснащення та практичних навичок.

На III році навчання студенти опановують в загальному організацію медичного забезпечення військ, виходячи із сучасних прийнятих в Україні науково обгрунтованих засад. Одночасно досконало вивчаються навички діяльності стрільця-санітара та санітарного інструктора роти під час виконання бойових дій (в умовах розроблених типових сценаріїв військового зіткнення, які повторюються 3 деякими доповненнями 3 II року навчання). Застосовуються додаткові засоби, які входять до комплекту медичного оснащення санітарного інструктора роти. Студенти отримують посвідчення санінструктора роти.
На IV році навчання студенти продовжують вивчати організацію медичного забезпечення військ і опановують діяльність медичного пункту батальйону із відпрацюванням тактики його застосування у різних видах бойових зіткнень та обсягів медичної допомоги (за сценаріями II і III років навчання). Одночасно вивчається дисципліна “Токсикологія, радіологія і медичний захист”, яка, крім бойових отруйних речовин, враховує загрози переважно екологічного характеру, які зумовлені веденням бойових дій у зоні екологічно небезпечних виробництв.

На V році навчання вивчаються військовоспеціальні дисципліни на клінічних базах, а також діяльність медичного пункту батальйону у військових частинах.

У канікулярний період відбувається навчальний збір на базі підготовлених військових підрозділів, під час якого студенти відпрацьовують реальні практичні навички в симульованих ситуаціях ведення бойових дій та надання різних видів допомоги (рівень батальйонного медичного пункту, дооснащеного лікарсько-сестринськими бригадами). Для навчального збору розробляються стандартні сценарії (починаючи із рядового солдата, закінчуючи начальником медичного пункту батальйону). Проводиться стройова підготовка, навчальні стрільби й прийняття Військової присяги.

На VI році навчання вдосконалюють знання i навички військово-спеціальних дисциплін. Одночасно на базі військової кафедри вдосконалюються навички роботи начальника медичного пункту батальйону. Студенти складають комплексний випускний іспит. Після отримання диплома отримують посвідчення помічника лікаря - начальника медичного пункту батальйону.

Під час інтернатури лікарі-інтерни опановують патологію, отриману внаслідок бойових дій за профільною спеціальністю. Розглядається організація і надання медичної допомоги у медичній роті механізованої бригади, військовому госпіталі. Ці питання включаються в підсумковий іспит та іспит “Крок-3”. Після успішного складання іспитів студент отримує посвідчення офіцера медичної служби запасу.

Протягом діяльності за фахом лікарі під час передатестаційних циклів проходять курс військової підготовки, під час якого повторно опановують теоретичні знання і відпрацьовують практичні навички з бойової патології за фахом та організації медичного забезпечення військ. Оптимальним $є$ 
використання клінічних баз військових госпіталів. Один раз у три роки проводиться 2-тижневий збір на базі профільних кафедр (військових частин) із відпрацюванням комплексу навичок (тактика, топографія, тактична медицина, медичний пункт батальйону, медична рота механізованої бригади, військовий госпіталь).

Підготовка і перепідготовка кадрів для потреб освітньої діяльності за програмою офіцера запасу здійснюється Українською військово-медичною академією із залученням польових навчальних баз.

Для студентів - майбутніх офіцерів запасу розробляється комплексна програма з військовопатріотичного виховання, організовуються олімпіади, конкурси, екскурсійні тури по місцях бойової слави Українського війська і т. п. Роздруковуються

\section{Список літератури}

1. Про затвердження Порядку проведення військової підготовки громадян України за програмою підготовки офіцерів запасу : Постанова КМ України від 1 лютого 2012 p. № 48. відповідні плакати, сценарії вечорів та унаочнення.

Таким чином, комплексний підхід, послідовне опанування теоретичних знань і практичних навичок дозволить сформувати гідного офіцерамедика.

Висновок. Військова підготовка за програмою офіцера медичної служби запасу повинна стати нормативною дисципліною, торкатися всіх студентів-медиків, які за станом здоров'я придатні до військової служби. Навчання відбувається послідовно із врахуванням сучасних досягнень військової медицини з постійною перепідготовкою на післядипломному рівні.

2. Про внесення змін до Постанови КМ України від 01.02.2012 р. № 48 : Постанова КМ України від 5 серпня 2015 р. № 577.

Отримано 04.09.15 